\title{
Article
}

Mycosphere

\section{Diaporthe toxicodendri sp. nov., a causal fungus of the canker disease on Toxicodendron vernicifluum in Japan}

\author{
Ando $\mathbf{Y}^{1}$, Masuya $\mathbf{H}^{1}$, Aikawa $\mathbf{T}^{1}$, Ichihara $\mathbf{Y}^{2}$ and Tabata $\mathbf{M}^{\mathbf{1}^{*}}$ \\ ${ }^{1}$ Tohoku Research Center, Forestry and Forest Products Research Institute (FFPRI), 92-25 Nabeyashiki, Shimo- \\ kuriyagawa, Morioka Iwate 020-0123, Japan \\ ${ }^{2}$ Kansai Research Center, Forestry and Forest Products Research Institute (FFPRI), 68 Nagaikyutaroh, Momoyama, \\ Fushimi, Kyoto, Kyoto 612-0855, Japan
}

Ando Y, Masuya H, Aikawa T, Ichihara Y, Tabata M 2017 - Diaporthe toxicodendri sp. nov., a causal fungus of the canker disease on Toxicodendron vernicifluum in Japan. Mycosphere 8(5), 1157-1168, Doi 10.5943/mycosphere/8/5/6

\begin{abstract}
We describe for the first time the fungus Diaporthe toxicodendri sp. nov., which causes canker disease on the stems and twigs of Toxicodendron vernicifluum. We conducted a phylogenetic analysis using combined multigene sequence data from the rDNA internal transcribed spacer sequence and partial genes for calmodulin, histone $\mathrm{H} 3$, beta-tubulin, and translation elongation factor 1 -alpha. The results indicate that $D$. toxicodendri occupies a monophyletic clade with high support. Although 10 species are phylogenetically closely related to D. toxicodendri, morphological characteristics of size of alpha conidia and lacking of beta and gamma conidia support the distinction of this fungus from those closely related species. No sexual morphic structures have yet been found for the species. The pathogenicity of this species was confirmed by the inoculation test to T. vernicifluum.
\end{abstract}

Key words - Anacardiaceae - canker disease - Diaporthales - Phomopsis - taxonomy

\section{Introduction}

Toxicodendron vernicifluum (Stokes) F.A. Barkley is a deciduous tree belonging to the family Anacardiaceae. The tree has economic and cultural importance as its resin is used to make lacquer (Miyamoto \& Kakuda 2008). Recently, outbreaks of a canker disease have occurred at $T$. vernicifluum plantations in Hokkaido, Aomori, and Iwate Prefectures of northern Japan (Tabata pers. obs., Takemoto et al. 2014). Fungal species of the genus Phomopsis (Sacc.) Bubák have frequently been detected in lesions of the diseased trees, but the causal agent has not previously been identified (Takemoto et al. 2014).

The genus name Phomopsis has been used for the asexual morphs of Diaporthe species Nitschke (Diaporthales, Ascomycota). However, due to recent changes of the International Code of Nomenclature for algae, fungi, and plants, the sexual and asexual morphs of a single species must now have the same name (Hawksworth et al. 2011, Wingfield et al. 2012). The name Diaporthe over Phomopsis was proposed for this group due to its prior use (Udayanga et al. 2012, Gomes et al. 2013), and here we follow this suggestion.

The genus Diaporthe includes many important pathogens that cause dieback and canker diseases on a wide variety of woody and herbaceous plants (Rehner \& Uecker 1994, Udayanga et 
al. 2011, Gomes et al. 2013). Large numbers of Diaporthe species and their asexual morphs have been described, but their taxonomy is confused. A taxonomic revision of the species and a new delimitation of the genus has been proposed, based on analyses of multi-locus DNA sequence data (e.g. Gomes et al. 2013, Udayanga et al. 2014a, b, Dissanayake et al. 2017). Udayanga et al. (2012) reassessed the species in Diaporthe using multi-locus phylogenetic analysis and proposed the phylogenetic species recognition should be applied to this genus. Gomes et al. (2013) also supported to adopt the phylogenetic species recognition for Diaporthe by multi-locus phylogeny using 243 Diaporthe isolates. Udayanga et al. (2014a, b) promoted this species recognition and resolved species boundaries of taxonomically confused groups, that are $D$. eres species complex and species on Citrus together with related Diaporthe species. In the most recent phylogenetic study, Dissanayake et al. (2017) revealed taxonomic status of 171 Diaporthe species used available ex-type isolates by multi-locus phylogenetic analysis. Several new species have been described according to this delimitation, especially from Asia (Tan et al. 2013, Gao et al. 2014, 2016, Fan et al. 2015, Udayanga et al. 2015, Du et al. 2016, Tanney et al. 2016). However, many unknown and/or ambiguous species from all over the world are still waiting to be defined and described.

Three Diaporthe and 2 Phomopsis species were listed in Japan in 1917 (Shirai \& Miyake 1917). Later, Hara (1954) identified 42 more species of Diaporthe and Phomopsis from various woody and herbaceous plants. However, some of these may have been misidentified. Kobayashi (1970) studied the Japanese Diaporthaceae fungi and recognized 19 species in the Diaporthe genus, providing detailed morphological descriptions and illustrations. Thereafter, several additional Diaporthe or Phomopsis species have been reported in fruit trees and agricultural crops in Japan (Kajitani \& Kanematsu 2000, Kishi 1998, Katsumoto 2010). Among these, a species of diaportalean fungus associated with Toxicodendron was reported as Diaporthe spiculosa (Westend.) Nitschke (Kobayashi 1970). However, D. spiculosa lacked the asexual morphic state and it was different from the Diaporthe spp. reported as Phomopsis by Takemoto et al. (2014).

The aims of the present study are to clarify the taxonomic position of the causal agent of canker disease on Toxicodendron vernicifluum using combined multi-gene sequences as in recent studies (e.g., Gomes et al. 2013, Udayanga et al. 2014b) as well as morphological characteristics and to confirm the pathogenicity of this fungus.

\section{Materials \& Methods}

\section{Fungal isolation}

Eight samples were collected from the stems and twigs of Toxicodendron vernicifluum in the plantations at Hokkaido, Aomori, and Iwate Prefectures in northern Japan. Isolates were obtained from the samples using single conidia or hyphae.

For single conidial isolation, spore masses were picked from the samples, suspended in 500 $\mu \mathrm{l}$ distilled water, and streaked onto the $1 \%$ malt extract agar (MA) plates. Single hyphae germinated from single conidia were then transferred to $2 \%$ MA plates.

For single hyphal isolation, tissue fragments were punched out from visible lesions on collected twigs using a $4 \mathrm{~mm}$ cork borer. The fragments were immersed in $70 \%$ ethanol for $30 \mathrm{~s}$ and in sodium hypochlorite solution (1\% available chlorine) for $3 \mathrm{~min}$, rinsed twice in sterile distilled water, and blotted dry on sterile filter paper for $15 \mathrm{~min}$. Each fragment was placed on the surface of $1 \%$ MA plate. The plates were incubated at $15^{\circ} \mathrm{C}$ in the dark and observed intermittently under a dissecting microscope. Any single hypha growing from a fragment was isolated and transferred to a $2 \%$ MA plate and maintained.

The pure cultures were used for culture characterization, optimal growth temperature assessment, molecular phylogenetic analysis, and inoculation. Isolates obtained in this study were deposited in the Forestry and Forest Products Research Institute (FFPRI) culture collection at Tsukuba, Japan, or author's culture collection (AYC). The specimens collected in this study were deposited in the Herbarium of Forest Mycology and Pathology (TFM) of FFPRI. 
Table 1 Isolate and GenBank accession numbers used in this study.

\begin{tabular}{|c|c|c|c|c|c|c|}
\hline \multirow{2}{*}{ Species } & \multirow{2}{*}{ Isolate $^{a}$} & \multicolumn{5}{|c|}{ GenBank accession number ${ }^{b}$} \\
\hline & & ITS & CAL & HIS & EF-1 $\alpha$ & BT \\
\hline D. ampelina & CBS $114016^{\mathrm{T}}$ & AF230751 & AY745026 & $\overline{-}$ & AY745056 & JX275452 \\
\hline D. betulicola & CFCC $51128^{\mathrm{T}}$ & KX024653 & KX024659 & KX024661 & KX024655 & KX024657 \\
\hline D. carpini & CBS 114437 & KC343044 & KC343286 & KC343528 & KC343770 & KC344012 \\
\hline D. detrusa & CBS 109770 & KC343061 & KC343303 & KC343545 & KC343787 & KC344029 \\
\hline D. fibrosa & CBS 109751 & KC343099 & КC343341 & KC343583 & KC343825 & КC344067 \\
\hline D. impulsa & CBS 114434 & KC343121 & KC343363 & KC343605 & KC343847 & KC344089 \\
\hline D. juglandicola & CFCC $51134^{\mathrm{T}}$ & KU985101 & KX024616 & KX024622 & KX024628 & KX024634 \\
\hline D. padi var. padi & CBS 114649 & КC343170 & KC343412 & КC343654 & KC343896 & KC344138 \\
\hline D. rostrata & CFCC $50062^{\mathrm{T}}$ & KP208847 & KP208849 & KP208851 & KP208853 & KP208855 \\
\hline D. scobina & CBS 251.38 & KC343195 & KC343437 & KC343679 & KC343921 & KC344163 \\
\hline D. thunbergii & MFLUCC $100576^{\mathrm{T}}$ & JQ619893 & JX197440 & - & JX275409 & JX275449 \\
\hline \multirow[t]{8}{*}{ D. toxicodendri sp. nov. } & FFPRI420984 & LC275189 & LC275197 & LC275205 & LC275213 & LC275221 \\
\hline & FFPRI420985 & LC275190 & LC275198 & LC275206 & LC275214 & LC275222 \\
\hline & FFPRI411163 & LC275191 & LC275199 & LC275207 & LC275215 & LC275223 \\
\hline & FFPRI420987 T & LC275192 & LC275200 & LC275208 & LC275216 & LC275224 \\
\hline & FFPRI420990 & LC275193 & LC275201 & LC275209 & LC275217 & LC275225 \\
\hline & FFPRI420991 & LC275194 & LC275202 & LC275210 & LC275218 & LC275226 \\
\hline & FFPRI411164 & LC275195 & LC275203 & LC275211 & LC275219 & LC275227 \\
\hline & FFPRI411165 & LC275196 & LC275204 & LC275212 & LC275220 & LC275228 \\
\hline D. woolworthii & CBS 148.27 & KC343245 & KC343487 & КC343729 & КC343971 & KC344213 \\
\hline
\end{tabular}

${ }^{\mathrm{a}}$ Ex-type or ex-epitype isolates are marked by $\mathrm{T}$.

${ }^{\mathrm{b}}$ Sequences obtained in this study are shown in bold.

\section{Morphological observations}

Samples were dissected and sectioned under a stereomicroscope using flame-sterilized scalpels and tweezers. Fungal structures were mounted in Shear's fluid (Chupp 1940) on glass slides and observed under a differential interference contrast microscope (Leica DM2500, Leica microsystems Inc.). Fifteen pycnidia and more than 150 conidia were selected randomly and measured to calculate the averages and ranges.

In order to determine the optimal temperatures for growth in culture, 3 isolates (FFPRI420984, FFPRI420985, and FFPRI420987) were selected. Sterile cork borers (5 mm diam.) were used to cut disks from the margins of colonies that had been growing actively on potato dextrose agar (PDA) for one month, and the disks were transferred to the centers of fresh $90 \mathrm{~mm}$ PDA plates. Incubations were carried out in the dark at $5-30^{\circ} \mathrm{C}$ with $5^{\circ} \mathrm{C}$ intervals. Three replications were conducted for each isolate. The average diameter of each culture was measured at $3,5,7$, and 14 days or until the mycelial growth reached the edges of the plates.

\section{DNA extraction, PCR amplification, and sequencing}

The 8 isolates were cultured on PDA for two weeks before sampling for molecular phylogenetic analyses. DNA was extracted from mycelial samples using the Prepman ${ }^{\circledR}$ Ultra Sample Preparation Reagent (Applied Biosystems, Foster City, CA, USA) according to the manufacture's protocol.

The following sequences were used in the analysis: the internal transcribed spacer (ITS) region of the ribosomal RNA genes and portions of the calmodulin (CAL), histone H3 (HIS), translation elongation factor 1 -alpha $(\mathrm{EF}-1 \alpha)$, and $\beta$-tubulin $(\mathrm{BT})$ genes. The sequences were amplified by the polymerase chain reaction (PCR) using the primers ITS5 and ITS4 (White et al. 1990) for the ITS; CAL563F (Udayanga et al. 2014b) and CL2A (O'Donnell et al. 2000) for CAL; CYLH3F (Crous et al. 2004) and H3-1b (Glass \& Donaldson 1995) for HIS; EF1-728F and EF1986R (Carbone \& Kohn 1999) for EF-1 $\alpha$; and T1 (O’Donnell \& Cigelnik 1997) and Bt2b (Glass \& Donaldson 1995) for BT. PCR reactions were set up using the GoTaq® Green Master Mix (Promega, Madison, WI, USA). Amplifications were performed in a BioRad iCycler (Bio-Rad Laboratories, Hercules, CA, USA) following the protocols of Gomes et al. (2013) for HIS and Udayanga et al. (2014) for ITS, CAL, EF-1 $\alpha$, and BT. 
The PCR products were separated by electrophoresis in $1 \%$ agarose gels stained with ethidium bromide and visualized under UV light. The products were purified using the ExoSAP-IT PCR Product Cleanup kit (Affymetrix Japan, Tokyo, Japan) and sequenced using the BigDyeTM Terminator Cycle Sequencing Kit v.3.1 (Applied Biosystems) with both forward and reverse primers. The sequences were analyzed with an ABI PRISM 3100 Genetic Analyzer (Applied Biosystems), assembled and edited using BioEdit ver. 7.2.5 (Hall 1999), and then deposited in GenBank (Table 1).

\section{Phylogenetic analyses}

We made two datasets (dataset I and II) to the estimate phylogenetic position of current fungus in the Diaporthe. Dataset I was composed of the combined multi-locus sequence data from the ITS, BT, EF-1 $\alpha$, and CAL sequences. The sequences were combined and aligned with reference sequences obtained from GenBank. The reference sequences had been used in most recent phylogenetic study of Diaporthe (Dissanayake et al. 2017). Dataset II was composed of the combined multi-locus sequence data from the ITS, CAL, HIS, EF-1 $\alpha$ and BT of closely related species to current fungus estimated by the phylogenetic analysis of dataset I (Table 1). In both dataset, alignments were performed using the online version of MAFFT 7 (http://mafft.cbrc.jp/alignment/server/) (Katoh \& Standly 2013) with the G-INS-i option. Sequences were manually edited when necessary using BioEdit ver. 7.2.5 (Hall 1999).

The phylogenetic trees were generated by maximum parsimony (MP), maximum likelihood (ML), and Bayesian inference (BI) analyses. The best fit evolutionary model was determined via the corrected Akaike informative criterion (AICc) (Akaike 1974, Sugiura 1978) for MP analysis and the Bayesian information criterion (BIC; Schwarz 1978) for BI analysis using the Kakusan 4 nucleotide substitution model selection program (Tanabe 2007, 2011).

The MP analysis was performed using PAUP* version 4.0b10 software (Swofford 2002) with the heuristic search and step-wise addition options and 1000 replications. All characters had equal weight and gaps were treated as missing data. The branch-swapping algorithm was tree bisection and reconstruction. The best tree was automatically selected using the Kishino-Hasegawa likelihood test (Kishino \& Hasegawa 1989) that is part of the PAUP* software. The tree length (TL), consistency index (CI), retention index (RI), rescaled consistency index (RC), and homoplasy index (HI) were calculated. Bootstrap analyses were performed using a heuristic search algorithm with 10,000 random addition replicates and nearest-neighbor interchange branch swapping. The ML analysis was performed using RAxML 8.0.2 software (Stamatakis 2014) with the GTR + Gamma model of evolution and 1,000 bootstrap replicates. The BI analysis was performed using MrBayes5D v.3.1.2.2012.12.13 (Tanabe 2008), which is a modified version of MrBayes v.3.1.2 (Ronquist \& Huelsenbeck 2003), to estimate the posterior probabilities of tree topologies with Markov Chain Monte Carlo (MCMC) searches. The BI analysis was performed for 10,000,000 generations and trees were sampled every 500 generations. Convergence of the MCMC procedure was assessed by calculating the effective sampling size using Tracer 1.6 (Rambaut et al. 2014). The first 2001 trees were discarded as burn-in. The support of nodes was tested based on posterior probabilities obtained from a 50\% majority rule consensus after deleting the trees in the burn-in period. Diaporthella corylina Lar.N. Vassiljeva and Diaporthe scobina Nitschke and D. thunbergii Udayanga, X.Z. Liu \& K.D. Hyde were used for the outgroup in dataset I and II, respectively.

\section{Inoculation}

Four to Nine yr-old of ten Toxicodendron vernicifluum trees ( 1.5 to $3.4 \mathrm{~m}$ high, 1.6 to $3 \mathrm{~cm}$ in diam. at breath height) were used. They were planted in the plantation of Ninohe City. Two Isolates, FFPRI420984 and AYC128-1, were grown on $90 \mathrm{~mm}$ PDA plate at $25^{\circ} \mathrm{C}$ for two weeks and used for inocula.

Each tree was inoculated with two isolates and control on 26 May 2017. The bark plugs (5 mm diam.) were triplicatedly removed by using sterile cork borer and replaced with each inoculum. The inoculation was made at the heights of about $0.6,0.9$ and $1.2 \mathrm{~m}$ on the stem of each tree. 
Inoculum discs were placed into the wounds. Each inoculation point was then covered with plastic film (Parafilm) and adhensive tape.

Inoculated trees were cut down and examined four weeks after inoculation. The bark was peeled and the maximum extent of lesions was measured, and results were expressed as the range, average and standard deviation of necrotic lesions of 30 inoculation points in ten trees. Seven to nine pieces of bark were cut, transferred onto $1 \%$ MA plates and incubated at $20^{\circ} \mathrm{C}$ for $3 \mathrm{wk}$. to confirm the presence of the inoculated fungi. The length and width of the lesions were analyzed by the Steel-Dwass test $(P<0.05)$ to assess the significant differences among the two inocula and the control.

\section{Results}

\section{Sample collection and Morphological characteristics}

We found 1-4 y old T. vernicifluum trees diseased with canker in Hokkaido, Aomori, and Iwate Prefectures and identified the asexual morph of Diaporthe in the diseased parts of the trees (Fig 2A). This fungus was frequently isolated from pycnidia produced on stems and twigs, and also from bark tissues in canker-diseased lesions. The pycnidia were scattering over the stems and twigs and produced conspicuous yellowish cream colored conidial masses on their tips when mature (Fig 2B). We used these pycnidia for observation of morphological characters. This fungus was characterized by lacking beta and gamma conidia (Fig 2G). Sexual morph structures were not found on natural substrates and were not observed even after twigs with pycnidia collected at Iwate Pref. were incubated on artificial media.

\section{Phylogenetic analyses}

The dataset I was contained the sequences from our 8 isolates with 179 available sequences including 171 ex-type sequences used by Dissanayake et al. (2017). This dataset was composed of 2608 sites (ITS $=545, \mathrm{BT}=970, \mathrm{EF}-1 \alpha=634, \mathrm{CAL}=459)$ including gaps. The result of this analysis indicated that this fungus grouped in monophyletic clade in Diaporthe and closely related to 10 species (data not shown, but this alignment file and phylogenetic tree were deposited in TreeBASE: S20847).

The dataset II used in this study was composed of 2523 sites (ITS $=476, \mathrm{CAL}=482, \mathrm{HIS}=$ $500, \mathrm{EF}-1 \alpha=358, \mathrm{BT}=707$ ) including alignment gaps. We analyzed the sequences from our 8 isolates with 12 other available sequences, including the outgroup. This combined multigene dataset was deposited in TreeBASE (http://purl.org/phylo/treebase/phylows/study/TB2:S20847) as S20847. In this dataset, 1884 sites were constant, and there were 313 variable sites that were uninformative. The MP analysis was performed used the remaining 326 parsimony informative characters, and one parsimonious tree was obtained $(\mathrm{TL}=961, \mathrm{CI}=0.7919, \mathrm{RI}=0.8241, \mathrm{RC}=$ $0.6526, \mathrm{HI}=0.2081$ ). The results of the ML analysis are shown in Fig. 1.

The phylogenetic analyses showed that this fungus is closely related to 10 other Diaporthe species: D. impulsa (Cooke \& Peck) Sacc., D. ampelina (Berk. \& M.A. Curtis) R.R. Gomes, Glienke \& Crous, D. fibrosa (Pers.) Fuckel, D. detrusa (Kunze) Fuckel, D. carpini (Pers.) Fuckel, D. padi var. padi G.H. Otth, D. juglandicola Q. Yang, D. rostrata C.M. Tian, X.L. Fan \& K.D. Hyde, D. woolworthii (Peck) Sacc., and D. betulicola C.M. Tian \& Z. Du. However, this fungus was clustered in a distinct clade from the 10 other species with highly supported values (ML / MP / $\mathrm{BI}=100 / 100 / 1)$ (Fig.1).

\section{Taxonomy}

Diaporthe toxicodendri Y. Ando, Masuya et Tabata, sp. nov.

Etymology - from genus name of host. 


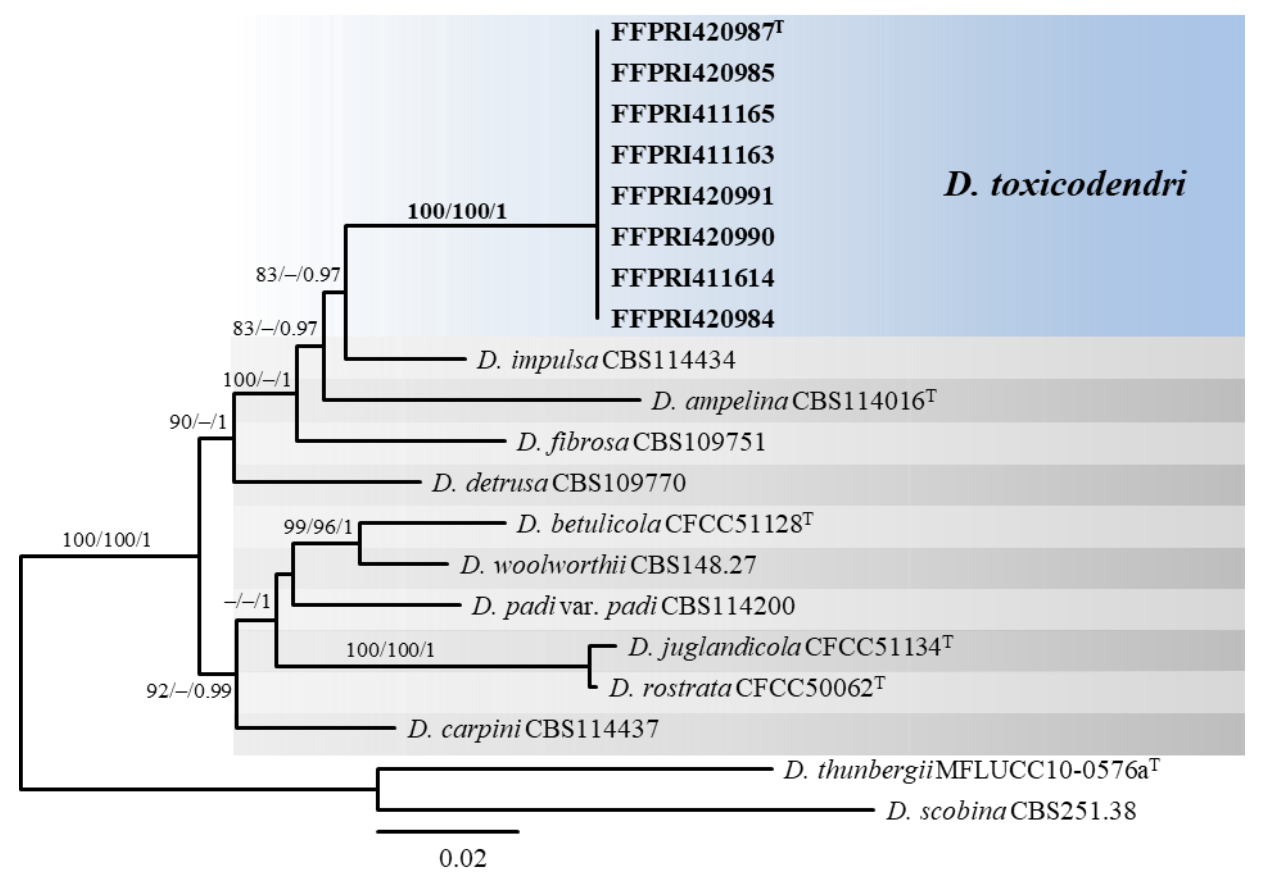

Figure 1 - The maximum likelihood tree based on the combined ITS, CAL, HIS, EF-1 $\alpha$, and BT genes dataset (composed of 20 OTUs and 2523 sites including gaps) of D. toxicodendri and closely related Diaporthe species. The support values for nodes are shown: left, $\geq 75$ maximum likelihood bootstrap; middle, $\geq 75$ maximum parsimony bootstrap; right, $\geq 0.95$ bayesian inference. $T$ : Ex-type or ex-epitype isolate. The isolates of the current study are shown in bold. Outgroup are used $D$. scobina (CBS 251.38) and D. thunbergii (MFLUCC 100576).

Sexual morph: unknown. Asexual morph on the stems and twigs of T. vernicifluum: Conidiomata pycnidial (Fig 2C-E), brown to dark brown, subglobose to obrate, immersed, scattered, up to $1 \mathrm{~mm}$ diam, solitary, embedded in tissue, erumpent at maturity, with an elongated, black neck less than $200 \mu \mathrm{m}$ long, cream conidial droplets exuding from central ostiole. Locules 462-985 × 126-278 $\mu \mathrm{m}$ (ave. $=638 \times 194 \mu \mathrm{m}, \mathrm{n}=15)($ Fig 2E), undivided, obrate to conoid. Conidiophores 13-30(-35) $\times 1.5-3.5(-4.0) \mu \mathrm{m}$ (ave. $=21.4 \times 2.5 \mu \mathrm{m}, \mathrm{n}=150)$, hyaline $($ Fig $2 \mathrm{~F})$, smooth, 0-1 septate, rarely branched, cylindrical to ampulliform, densely aggregated, straight. Conidiogenous cells (8.0-)8.5-19.5(-23.5) $\times 1.5-3.5 \mu \mathrm{m}(\mathrm{ave} .=13.9 \times 2.1 \mu \mathrm{m}, \mathrm{n}=150)$, phialidic, hyaline to pale brown at the base, cylindrical, terminal, slightly tapering towards apex. Paraphyses absent. Alpha conidia 8.5-13(-14) $\times 2.5-4 \mu \mathrm{m}$ (ave. $=10.9 \times 3.1 \mu \mathrm{m}, \mathrm{n}=200$ ), hyaline (Fig $2 \mathrm{G})$, aseptate, smooth, ellipsoid to oblong, straight to variously curved, tapering towards both ends. Beta and Gamma conidia not seen.

Culture characteristics - Colonies on PDA (Fig. 2H) covering the entire $90 \mathrm{~mm}$ plate after 7 days in the dark at $25^{\circ} \mathrm{C}$; surface canescent with abundant white compact aerial mycelium; reverse white to canescent at first, then becoming pale brown to dark brown towards the center. The optimal growth temperature is $25^{\circ} \mathrm{C}$ with growth in the range $5^{\circ} \mathrm{C}$ to $30^{\circ} \mathrm{C}$.

Material examined - JAPAN, Joboji, Ninohe, Iwate Pref., on the stem of Toxicodendron vernicifluum, 26 May 2011, coll. M. Tabata (holotype: TFM FP-10740, ex-type culture: FFPRI420987). JAPAN, Joboji, Ninohe, Iwate Pref., on the stem of T. vernicifluum, 24 May 2011, coll. M. Tabata (TFM FP-10739, living culture FFPRI420985); JAPAN, Joboji, Ninohe, Iwate Pref., on the twig of T. vernicifluum, 24 June 2013, coll. H. Masuya (TFM FP-10743); JAPAN, Joboji, Ninohe, Iwate Pref., on the twig of T. vernicifluum, 6 May 2016, coll. H. Masuya, (TFM FP-10744, living culture FFPRI411165).

Known distribution - Japan (Hokkaido, Aomori, and Iwate-Prefectures)

Known host - Toxicodendron vernicifluum (Anacardiaceae) 

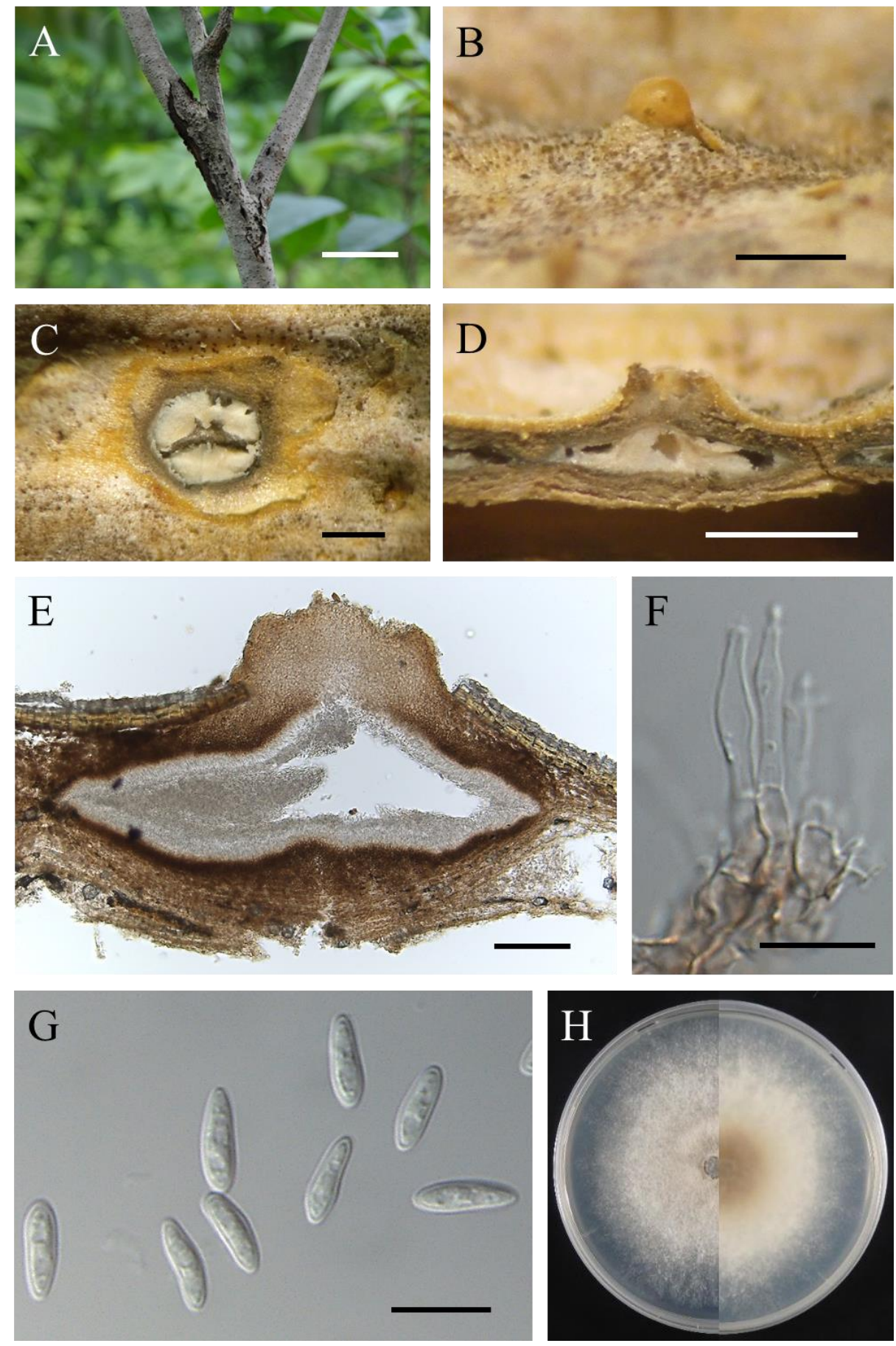

Figure 2 - Diaporthe toxicodendri. A: Disease symptom on Toxicodendron vernicifluum. B: Pycnidial exudates (TFM FP-10739). C: Horizontal section of the pycnidium (TFM FP-10739). DE: Longitudinal section of pycnidium (TFM FP-10739). F: Conidiophores (TFM FP-10744). G: Conidia (TFM FP-10740). H: Culture morphology incubated after 7 days in $25^{\circ} \mathrm{C}$, darkness (left: surface, right: reverse) (FFPRI420987). - Scale bars: B-D $=0.5 \mathrm{~mm}, \mathrm{E}=100 \mu \mathrm{m}, \mathrm{F}-\mathrm{G}=10 \mu \mathrm{m}$.

\section{Inoculation}

All the inoculated point of $D$. toxicodendri isolates showed spindle shaped necrotic lesions in the inner barks, while there were almost no necrotic lesions in those of the mock inoculation (control). Compared to the length and width of the lesions in the bark of control, two $D$. toxicodendri isolates were formed necrotic lesions with significantly differences (Table 2). Moreover, it was indicated the significantly differences between two isolates. It was suggested that 
virulence of D. toxicodendri was different between the isolates. Diaporthe toxicodendri was reisolated from the lesions of all inoculated trees.

Table 2 Dimensions of necrotic lesions in the inner bark of $T$. vernicifluum inoculated with $D$. toxicodendri isolates.

\begin{tabular}{lll}
\hline Inoculum & Length of necrotic lesions $(\mathrm{mm})^{\mathrm{a}}$ & ${\text { Width of necrotic lesions }(\mathrm{mm})^{\mathrm{a}}}^{\mathrm{a}}$ \\
\hline FFPRI420984 & $8.4-22.9(11.7 \pm 3.3) \mathrm{b}$ & $7.4-12.7(8.8 \pm 1.3) \mathrm{b}$ \\
AYC128-1 & $9.7-54.3(18.7 \pm 10.2) \mathrm{c}$ & $6.8-15.9(10.3 \pm 1.9) \mathrm{c}$ \\
Control & $7.8-10.8(8.9 \pm 0.7) \mathrm{a}$ & $6.3-8.4(7.6 \pm 0.5) \mathrm{a}$ \\
\hline
\end{tabular}

a Values indicate Min. - Max. (Ave. \pm SD) followed by the different letter are significantly different $(\mathrm{P}=0.05)$ by the Steel-Dwass test.

\section{Discussion}

In this study we describe Diaporthe toxicodendri as a novel species based on both morphological characteristics and phylogenetic analyses using combined multigene sequences. The phylogenetic analyses showed this species is closely related to 10 species of Diaporthe (Fig. 1). These closely related species are known as pathogen of leaf spot, canker or dieback disease and widely or narrowly distributed in northern hemisphere (Gomes et al. 2013). Most of these species have been described from Europe or North America, three novel species were recently introduced in this group from China (Fan et al. 2015, Du et al. 2016, Yang et al. 2017). Although 6 of these species (D. impulsa, D. fibrosa, D. detrusa, D. carpini, D. padi var. padi, and D. woolworthii) were included in phylogenetic analysis by Gomes et al. (2013), the sequences from type material are unavailable. The epi- or neotypification for these species are needed in further study. In the morphological comparison with these closely related species (Table 3), D. impulsa, D. ampelina, $D$. betulicola, and $D$. detrusa could be distinguished from $D$. toxicodendri based on the existence of beta conidia. These 4 species are known to produce beta conidia on natural substrates and/or culture medium (Wehmeyer 1933, Gomes et al. 2013, Du et al. 2016). On the other hand, D. toxicodendri did not form conidiomata after twigs were placed on culture media. D. toxicodendri could also be distinguished from D. fibrosa (Saccardo 1882) and D. rostrata (Fan et al. 2015), which have wider alpha conidia than those of $D$. toxicodendri, and D. toxicodendri form large size of alpha conidia in comparison to D. junlandicola (Yang et al. 2017). The remaining 3 species, D. woolworthii, D. padi var. padi, and D. carpini, were provided using putatively named strains by Gomes et al. (2013), and were difficult to distinguish from $D$. toxicodendri by morphology. However, $D$. toxicodendri was clearly differentiated from these species in the phylogenetic analysis with high supported values (Fig. 1).

Different Diaporthe species associated with Anacardiaceae plants can have wide host ranges or be host specific (Gomes et al. 2013). According to the U.S. National Fungus Collections Database (United States Department of Agriculture, https://nt.arsgrin.gov/fungaldatabases/fungushost/fungushost.cfm), a total of 25 Diaporthe species have been isolated from Anacardiaceae plants worldwide. Most of these species produce smaller alpha conidia than D. toxicodendri and others lack alpha conidia or produce beta conidia (Spegazzini 1910, Wehmeyer 1933, Srivastava et al. 1966, Kobayashi 1970, Sutton 1980, Uecker \& Kuo 1992, Punithalingam 1993, Gomes et al. 2013, Udayanga et al. 2014b). One Diaporthe species associated with Anacardiaceae plant according to Gomes et al. (2013), Diaporthe sp. 7, was not included in the phylogenetic analyses in this study. However, D. toxicodendri is distantly related to this species. Therefore, the known Diaporthe species associated with Anacardiaceae are not closely related to $D$. toxicodendri.

Currently, over 80 Diaporthe species have been identified in Japan (Katsumoto 2010) but this list includes species that need re-examination with molecular data. Japanese Diaporthe isolates from fruit trees, agricultural crops, and forest trees are deposited in the National Institute of Agrobiological Sciences (NIAS) Genebank (Tsukuba, Ibaraki, Japan). ITS sequence data for 207 
Diaporthe isolates, including 33 identified and unidentified species, are provided at the NIAS Genebank website (https://www.gene.affrc.go.jp/databases-micro_search.php). However, the $D$. toxicodendri ITS sequences did not match the sequences of any isolate in that database. It appears

Table 3 The comparison of size of alpha and beta conidia of Diaporthe toxicodendri and closely related species.

\begin{tabular}{|c|c|c|c|c|}
\hline Species & Host (family) & Alpha conidia $(\mu \mathrm{m})$ & Beta conidia $(\mu \mathrm{m})$ & Reference \\
\hline D. toxicodendri & $\begin{array}{l}\text { Toxicodendron vernicifluum } \\
\text { (Anacardiaceae) }\end{array}$ & $8.5-13(-14) \times 2.5-4.0$ & - & This study \\
\hline D. impulsa & $\begin{array}{l}\text { Sorbus. americana, } S . \\
\text { aucuparia (Rosaceae) }\end{array}$ & $15-27 \times 2.5-5$ & $10-15 \times 1-1.5$ & Wehmeyer (1933) \\
\hline D. ampelina & Vitis vinifera (Vitaceae) & $\begin{array}{l}(7-) 9.5-10.5(-13) \times \\
(1.5-) 2-3(-3.5)\end{array}$ & $20-25 \times 0.5-1$ & Gomes et al. (2013) \\
\hline D. betulicola & $\begin{array}{l}\text { Betula albosinensis } \\
\text { (Betulaceae) }\end{array}$ & $10-14.5(15) \times 1.5-2.5$ & $17-24 \times 0.5-1(-1.5)$ & Du et al. (2016) \\
\hline D. detrusa & $\begin{array}{l}\text { Berberis microphylla, } B \text {. } \\
\text { spathulata, } B . \text { vulgaris } \\
\text { (Berberidaceae) } \\
\text { Mahonia aquifolia } \\
\text { (Berberidaceae) }\end{array}$ & $8-17 \times 2.5-3(-5)$ & $11-33 \times 1-1.5$ & Wehmeyer (1933) \\
\hline D. fibrosa & $\begin{array}{l}\text { Prunus spinose (Rosaceae), } \\
\text { Rhamnus cathartica, } R . \\
\text { frangula (Rhamunaceae), } \\
\text { S. aucuparia (Rosaceae) }\end{array}$ & $11 \times 5$ & - & Saccardo (1882) \\
\hline D. rostrata & $\begin{array}{l}\text { Juglans mandshurica } \\
\text { (Juglandaceae) }\end{array}$ & $\begin{array}{l}(8-) 8.5-11.5(-12) \times \\
4-5(-5.5)\end{array}$ & - & Fan et al. (2015) \\
\hline D. juglandicola & $\begin{array}{l}\text { J. mandshurica } \\
\text { (Juglandaceae) }\end{array}$ & $\begin{array}{l}(7.5-) 8-9(-9.5) \times \\
2.5-3(-3.2)\end{array}$ & - & Yang et al. (2017 \\
\hline D. woolworthii & $\begin{array}{l}\text { Ulmus americana } \\
\text { (Ulmaceae) }\end{array}$ & 10 & - & Saccardo (1882) \\
\hline D. padi var. padi & P. padus (Rosaceae) & $9-11 \times 3$ & - & Wehmeyer (1933) \\
\hline D. carpini & $\begin{array}{l}\text { Carpinus betulus } \\
\text { (Betulaceae) }\end{array}$ & $12 \times 3-4$ & - & Saccardo (1882) \\
\hline
\end{tabular}

-: not seen

that species consistent with $D$. toxicodendri have not previously been reported in Japan, although this may be due to confusion in the species identification of available isolates.

Takemoto et al. (2014) isolated several Diaporthe species (as Phomopsis species) from T. vernicifluum, and we have isolated $D$. toxicodendri predominantly from canker-diseased lesions in T. vernicifluum. In this study, we have confirmed the pathogenicity of the fungus to T. vernicifluum (Table 2). The result of inoculation suggested that this fungus had different virulence between the isolates. Further studies are needed to assess the aggressiveness of D. toxicodendri and to identify resistant varieties of $T$. vernicifluum for future cultivation.

\section{Acknowledgements}

This study was supported in part by Science and Technology Research Promotion Program for Agriculture, Forestry, Fisheries and Food Industry No.28027C "Development of High Urushi Lacquer Production and Utilization Technologies for the Succession of Urushi Lacquer Culture in Japan", and Grant-in Aid for Scientific Research No. 26242017 from the Japan Society for the Promotion of Science.

\section{References}

Akaike H. 1974 - A new look at the statistical model identification. IEEE transactions on automatic control 19, 716-723.

Carbone I, Kohn LM. 1999 - A method for designing primer sets for speciation studies in filamentous ascomycetes. Mycologia 3, 553-556.

Chupp C. 1940 - Further notes on double cover-glass mounts. Mycologia 32, 269-270. 
Crous PW, Groenewald JZ, Risède JM, Simoneau P, Hywel-Jones NL. 2004 - Calonectria species and their Cylindrocladium anamorphs: species with sphaeropedunculate vesicles. Studies in Mycology 50, 415-430.

Dissanayake AJ, Phillips AJL, Hyde KD, Yan JY et al. 2017 - The current status of species in Diaporthe. Mycosphere 8, 1106-1156.

Du Z, Fan XL, Hyde KD, Yang Q et al. 2016 - Phylogeny and morphology reveal two new species of Diaporthe from Betula spp. in China. Phytotaxa 269, 90-102.

Fan XL, Hyde KD, Udayanga D, Wu XY et al. 2015 - Diaporthe rostrata, a novel ascomycete from Juglans mandshurica associated with walnut dieback. Mycological Progress 14, 1-8.

Gao YH, Liu F, Cai L. 2016 - Unravelling Diaporthe species associated with Camellia. Systematics and Biodiversity14, 102-117.

Gao YH, Sun W, Su YY, Cai L. 2014 - Three new species of Phomopsis in Gutianshan Nature Reserve in China. Mycological Progress 13, 111-121.

Glass NL, Donaldson GC. 1995 - Development of primer sets designed for use with the PCR to amplify conserved genes from filamentous ascomycetes. Applied and Environmental Microbiology 61, 1323-1330.

Gomes RR, Glienke C, Videira SIR, Lombard L et al. 2013 - Diaporthe: a genus of endophytic, saprobic and plant pathogenic fungi. Persoonia 31, 1-41.

Hall TA. 1999 - BioEdit: a user-friendly biological sequence alignment editor and analysis program for Windows 95/98/NT. Nucleic Acids Symposium Series 41, 95-98.

Hara K. 1954 - A list of Japanese fungi hitherto known, fourth edition (in Japanese). Japanese Fungological Society, Gifu.

Hawksworth DL, Crous PW, Redhead SA, Reynolds DR et al. 2011 - The Amsterdam declaration on fungal nomenclature. IMA fungus 2, 105-112.

Kajitani Y, Kanematsu S. 2000 - Diaporthe kyushuensis sp. nov., the teleomorph of the causal fungus of grapevine swelling arm in Japan, and its anamorph Phomopsis vitimegaspora. Mycoscience 41, 111-114.

Katoh K, Standly DM. 2013 - MAFFT multiple sequence alignment software version 7: improvements in performance and usability. Molecular Biology and Evolution 30, 772-780.

Katsumoto K. 2010 - List of fungi recorded in Japan (in Japanese). Kanto Branch of the Mycological Society of Japan, Chiba.

Kishi K (ed) 1998 - Plant diseases in Japan (in Japanese). Zenkoku Noson Kyoiku Kyokai, Tokyo.

Kishino H, Hasegawa M. 1989 - Evaluation of the maximum likelihood estimate of the evolutionary tree topologies from DNA sequence data, and the branching order in Hominoidea. Journal of Molecular Evolution 29, 170-179.

Kobayashi T. 1970 - Taxonomic studies of Japanese Diaporthaceae with special reference to their life-histories. Bulletin of the Government Forest Experimental Station Meguro 226, 1-242.

Miyamoto M, Kakuda A (eds) 2008 - An Exhibition of Shisui Rokkaku, Who Established Japanese 'National Treasure' (in Japanese). Hiroshima Pref Art Mus, Hiroshima.

O’Donnell K, Cigelnik E. 1997 - Two divergent intragenomic rDNA ITS2 types within a monophyletic lineage of the fungus Fusarium are nonorthologous. Molecular Phylogenetics and Evolution 7, 103-116.

O’Donnell K, Nirenberg HI, Aoki T, Cigelnik E. 2000 - A multigene phylogeny of the Gibberella fujikuroi species complex: Detection of additional phylogenetically distinct species. Mycoscience 41, 61-78.

Punithalingam E. 1993 - IMI Descriptions of Fungi and Bacteria, Set 117, Nos 1161-1170. Mycopathologia 123, 41-64.

Rambaut A, Suchard MA, Xie D, Drummond AJ. 2014 - Tracer v1.6. Available from http://beast.bio.ed.ac.uk/Tracer.

Rehner SA, Uecker FA. 1994 - Nuclear ribosomal internal transcribed spacer phylogeny and host diversity in the coelomycete Phomopsis. Canadian Journal of Botany 72, 1666-1674. 
Ronquist F, Huelsenbeck JP. 2003 - MrBayes 3: Bayesian phylogenetic inference under mixed models. Bioinformatics 19, 1572-1574.

Saccardo PA. 1882 - Sylloge fungorum vol 1. Typis Seminarii, Italy (in Latin).

Schwarz G. 1978 - Estimating the dimension of a model. The Annals of Statistics 6, 461-464.

Shirai M, Miyake I. 1917 - A list of Japanese fungi hitherto known, Second edition (in Japanese). Tokyo Shuppan, Tokyo.

Spegazzini C. 1910 - Fungi chilenses. Revista de la Facultad de Agronomía y Veterinaria de La Plata 6, 1-205.

Srivastava MP, Tandon RN, Bhargava SN, Ghosh AK. 1966 - Studies on fungal diseases of some tropical fruits IV. Some new fungi. Mycopathologia et mycologia applicata 30, 203-208.

Stamatakis A. 2014 - RAxML version 8: a tool for phylogenetic analysis and post-analysis of large phylogenies. Bioinformatics 30, 1312-1313.

Sugiura N. 1978 - Further analysis of the data by Akaike's information criterion and the finite corrections. Communications in Statistics-Theory and Methods 7, 13-26.

Sutton BC. 1980 - The coelomycetes. Fungi imperfecti with Pycnidia, Acervuli and Stromata. Common wealth Mycological Institute, Kew, Surrey.

Swofford DL. 2002 - PAUP*: phylogenetic analysis using parsimony (and other methods), 4.0b10. Sinauer, Sunderland, MA.

Takemoto S, Masuya H, Tabata M. 2014 - Endophytic fungal communities in the bark of cankerdiseased Toxicodendron vernicifluum. Fungal Ecology 7, 1-8.

Tan YP, Edwards J, Grice KRE, Shivas RG. 2013 - Molecular phylogenetic analysis reveals six new species of Diaporthe from Australia. Fungal Diversity 61, 251-260.

Tanabe AS. 2007 - KAKUSAN: a computer program to automate the selection of a nucleotide substitution model and the configuration of a mixed model on multilocus data. Molecular Ecology Resources 7, 962-964.

Tanabe AS. $2008-$ MrBayes5D. Software distributed by the author at http://www.fifthdimension.jp/.

Tanabe AS. 2011 - Kakusan4 and Aminosan: two programs for comparing nonpartitioned, proportional and separate models for combined molecular phylogenetic analyses of multilocus sequence data. Molecular Ecology Resources 11, 914-921.

Tanney JB, Mcmullin DR, Green BD, Miller JD, Seifert KA. 2016 - Production of antifungal and antiinsectan metabolites by the Picea endophyte Diaporthe maritima sp. nov. Fungal Biology 120, 1448-1457.

Uecker FA, Kuo KC. 1992 - A new Phomopsis with long paraphyses. Mycotaxon 44, 425-433.

Udayanga D, Castlebury LA, Rossman AY, Chukeatirote E et al. 2015 - The Diaporthe sojae species complex: Phylogenetic re-assessment of pathogens associated with soybean, cucurbits and other field crops. Fungal Biology 119, 383-407.

Udayanga D, Castlebury LA, Rossman AY, Chukeatirote E, Hyde KD. 2014a - Insights into the genus Diaporthe: phylogenetic species delimitation in the D. eres species complex. Fungal Diversity 67, 203-229.

Udayanga D, Castlebury LA, Rossman AY, Hyde KD. 2014b - Species limits in Diaporthe: molecular re-assessment of $D$. citri, D. cytosporella, D. foeniculina and D. rudis. Persoonia 32, 83-101.

Udayanga D, Liu X, Crous PW, McKenzie EHC et al. 2012 - A multi-locus phylogenetic evaluation of Diaporthe (Phomopsis). Fungal Diversity 56, 157-171.

Udayanga D, Liu X, McKenzie EHC, Chukeatirote E et al. 2011 - The genus Phomopsis: biology, applications, species concepts and names of common phytopathogens. Fungal Diversity 50, $189-225$.

Wehmeyer LE. 1933 - The Genus Diaporthe Nitschke And Its Segretes. Michigan.

White TJ, Bruns T, Lee SJWT, Taylor JW. 1990 - Amplification and direct sequencing of fungal ribosomal RNA genes for phylogenetics. In: Innis MA, Gelfand DH, Shinsky JJ, White TJ 
(eds) PCR protocols: a guide to methods and applications. Academic Press, San Diego, pp 315-322.

Wingfield MJ, De Beer ZW, Slippers B, Wingfield BD et al. 2012 - One fungus, one name promotes progressive plant pathology. Molecular Plant Pathology 13, 604-613.

Yang Q, Fan XL, Du Z, Tian CM. 2017 - Diaporthe juglandicola sp. nov. (Diaporthales, Ascomycetes), evidenced by morphological characters and phylogenetic analysis. Mycosphere 8, 817-826. 